\title{
Smoke-free air policies: past, present and future
}

\author{
Andrew Hyland, ${ }^{1}$ Joaquin Barnoya, ${ }^{2,3}$ Juan E Corral ${ }^{2}$
}

${ }^{1}$ Department of Health Behavior Roswell Park Cancer Institute, Buffalo, New York, USA

${ }^{2}$ Departamento de Investigación, Unidad de Cirugía Cardiovascular de Guatemala, Guatemala City, Guatemala ${ }^{3}$ Division of Public Health Sciences, Department of Surgery, Washington University in St Louis, St Louis, Missouri, USA

\section{Correspondence to}

Dr Andrew Hyland, Department of Health Behavior, Roswell Park Cancer Institute, Elm and Carlton Streets, Buffalo, New York 14263, USA; andrew.hyland@roswellpark.org

Received 20 June 2011 Accepted 14 December 2011

\section{ABSTRACT}

Smoke-free policies have been an important tobacco control intervention. As recently as 20 years ago, few communities required workplaces and hospitality venues to be smoke-free, but today approximately $11 \%$ of the world's population live in countries with laws that require these places to be smoke-free. This paper briefly summarises important milestones in the history of indoor smoke-free policies, the role of scientific research in facilitating their adoption, a framework for smoke-free policy evaluation and industry efforts to undermine regulations. At present, smoke-free policies centre on workplaces, restaurants and pubs. In addition, many jurisdictions are now beginning to implement policies in outdoor areas and in shared multiunit housing settings. The future of smoke-free policy development depends on credible scientific data that documents the health risks of secondhand smoke exposure. Over the next 20 years smoke-free policies will very likely extend to outdoor and private areas, and changes in the types of tobacco products that are consumed may also have implications for the nature and scope of the smoke-free policies of the future.

\section{INTRODUCTION}

Smoke-free policies are different than other policies to reduce tobacco use because they primarily affect the non-smoker; hence, there is generally widespread population-based support for providing smoke-free spaces. ${ }^{1} 2$ Today, 28 countries have comprehensive policies in place covering $100 \%$ of all non-hospitality workplaces, bars and restaurants. ${ }^{3}$ In this paper, we define a comprehensive policy ban as one that bans smoking in all (no designated smoking rooms allowed) enclosed public places and workplaces, including bars, restaurants and public transportation. ${ }^{4}$ In the USA, California was the first state to require all workplaces, bars and restaurants to be smoke free, in 1998. Prior to this date, few comprehensive smoke-free policies were in place, anywhere in the world. This progress towards eliminating smoking inside public places represents a tremendous public health accomplishment, and has lead to reductions in heart disease and lung cancer rates. ${ }^{5-7}$ Scientific research has documented that secondhand smoke (SHS) is a serious health hazard. The results of these studies, often used by tobacco control advocates, have played a critical role in addressing other arguments raised by opponents during policy debates and will certainly shape the implementation of tobacco free policies in the future.

To help set the framework for discussing smokefree policies, there are two general types of policies: those that are mandated by law or regulation and those that are voluntarily adopted. In addition, smoke-free policies can be categorised as those that impact public areas and those that impact private areas. Prior to many legislated smoke-free workplace policies, it is typical that a large fraction of workplaces have already adopted some type of voluntary norm limiting where smoking is allowed on site. The legislated policy serves to streamline the rules for consistency, fairness and maximum protection closing gaps in SHS protection that result from voluntary norm adoption. Policies that impact private areas, such as homes and automobiles, have almost universally been voluntarily adopted to date. The policy arguments are somewhat different depending on which type of policy is being considered. Also note that we use the term 'policy' in a broad sense to reflect legislated or regulated policies as well as voluntary policies to require spaces to be smoke free.

In this paper we aim to briefly summarise sentinel events that are part of the evolution of smoke-free policies, current efforts, and key areas of research and challenges that we foresee may greet us in the future. Our account of the history of smoke-free policies is selective, and concentrates specifically on events in the USA.

\section{History of epidemiological evidence on the dangers of SHS}

In the USA, for most of the 20th century, smoking 'anywhere and at any time' was commonplace. Although backlash against SHS in public places also began during this period, smoking bans were rare. However, beginning in the 1960s, scientific research was pointing to real dangers as the direct results of SHS exposure. In the early 1970s, US Surgeon General Jesse L Steinfeld declared that non-smokers had a right to breathe clean indoor air at meetings such as the Interagency Committee on Smoking and Health. ${ }^{8}$ Shortly thereafter, the first US Surgeon General's report to mention exposures from air pollution from tobacco smoke (secondhand smoke) was released in 1972, stating that such exposures were likely to be harmful to the health of non-smokers. ${ }^{9}$

Two studies published in 1980 showed that secondhand smoke significantly exposed nonsmokers to tobacco particles and reduced their pulmonary function. ${ }^{10} 11$ The landmark study by Hirayama and colleagues in Japan published a year later using longitudinal data demonstrated that non-smoking wives of smokers or ex-smokers had significantly higher rates of lung cancer compared to non-smoking women married to non-smoking men. ${ }^{12}$ The tobacco industry organised a multimillion-dollar campaign designed to discredit Hirayama's paper, although they failed to do so. Now, 30 years later, Hirayama's findings have been confirmed by epidemiological and biological 
evidence from many other populations. ${ }^{13}$ Reviews by the International Agency for Research in Cancer and publications by Allan Brandt and Richard Kluger provide further highlights on the evolution of smoke-free indoor environments. ${ }^{8} 1415$

In 1986 the US Surgeon General's Report and US National Academy of Sciences (NAS) concluded that SHS causes lung cancer in non-smokers and is associated with a variety of respiratory conditions in children. ${ }^{16}$ In 1992 the US Environmental Protection Agency concluded that the widespread exposure to SHS in the USA presents a serious and substantial public health problem. ${ }^{17}$ The 2006 US Surgeon General's report stated, 'the debate is over' and 'the science is clear' that secondhand smoke causes lung cancer and heart disease in nonsmokers among many other conditions. ${ }^{18}$ The National Health and Medical Research Council of Australia (1997), the Scientific Committee on Tobacco and Health of the United Kingdom (1998) and the International Agency for Research on Cancer (2002) have reached similar conclusions. ${ }^{19}$

\section{The past smoke-free policy wave}

The first smoke-free initiatives, designed to reduce fire risks, can be traced back to the 18th century in Germany when smoking restrictions were instituted in towns, forests, barns and bedrooms. ${ }^{20}$ However, as cigarette smoking became more prevalent following the invention of the Bonsack machine in 1888, so did lobbying activities by pro-smoking and anti-smoking groups. ${ }^{8} 14$ The Non-Smokers Protective League in the USA, initiated in 1910, lobbied for smoke-free public places such as hotels and restaurants. ${ }^{8} 14$ However, smoking activists also lobbied for the rights of smokers by petitioning for repeals of smoking bans in certain locations and advocating for smoking areas in others. ${ }^{14}$

Public interest groups such as Action on Smoking and Health and grassroots organisations such as Group Against Smoking and Pollution were instrumental in the early smoke-free indoor air movement by petitioning for non-smoking sections in public places. ${ }^{14}$ By 1975, Arizona, Connecticut and Minnesota implemented the first policies in the USA that required some public places to be smoke free. ${ }^{18}$ In 1975, Minnesota became the first state in the USA to pass a comprehensive Clean Indoor Air Act, which banned smoking in most public work spaces. ${ }^{14}$ Even with significant lobbying activities by the tobacco industry, 36 states had some form of smoking restriction in place by $1981 .{ }^{14}$ Nearly 10 years after the 1986 Surgeon General's Report, in 1995, California became the first state to require all restaurants to be completely smoke free, and this policy was expanded to bars in 1998. As of October 2011, nearly $80 \%$ of the US population is covered by $100 \%$ smoke-free air legislation in non-hospitality workplaces and/or restaurants and/or bars. ${ }^{21}$ Out of 3397 municipalities that restrict where smoking is allowed, 628 have passed $100 \%$ smoke-free legislation pertaining to restaurants and bars. $^{22}$ Fundamental in the rationale for these policies is the epidemiological literature showing that SHS is associated with disease in non-smokers. The primary argument for smoke-free legislation has been that workers should not be required to inhale a toxic substance as a condition of employment. Without the scientific evidence, the rate of smoke-free policy adoption would surely have been slower.

Smoke-free aeroplanes also became a topic of considerable debate. Although many players were involved, including the US NAS, Group Against Smoking and Pollution and the Association for Non-Smokers Rights, ${ }^{14}$ from a workplace perspective, flight attendants were instrumental in spearheading the push for smoke-free policies. A 1986 report by the NAS pointed out that flight attendants were the group most significantly affected by smoke on aeroplanes, with their annual exposures estimated to be equivalent to that of living with a pack-a-day smoker. ${ }^{23}$ Given these high occupational exposures from SHS in crowded aeroplanes, ${ }^{24} 25$ the argument was made successfully to ban smoking on flights of $2 \mathrm{~h}$ or less (in 1988) and then to ban smoking on all US domestic flights. ${ }^{14}$

Through a court settlement in a flight attendant class action lawsuit against tobacco companies, the Flight Attendant Medical Research Institute was created. This is now the largest foundation that supports research on the detection, treatment and prevention of the diseases caused by SHS, and the Flight Attendant Medical Research Institute has played a critical role in establishing the science base for smoke-free policies. Additional support from workers rights movements came in 2002, when the International Commission on Occupational Health issued a position document stating that 'Employees at their workplace must not breathe air that is contaminated by tobacco smoke' and concluded that the only way to achieve smoke-free workplaces was through legislation, implementation and enforcement. ${ }^{26}$ In addition, personal court cases, such as that of Marlene Sharp, an Australian barmaid who developed laryngeal cancer due to SHS exposure, also helped to fuel media attention and transform ongoing public debates about particular policies. ${ }^{27}$

\section{The framework convention on tobacco control (FCTC) and smoke-free policies}

The WHO FCTC, the first global public health treaty, includes a provision in Article 8 that encourages countries to "protect citizens from exposure to tobacco smoke in the workplaces, public transport and indoor public places'. ${ }^{28}$ When this paper was written, 55 countries had national comprehensive smokefree laws, including 28 with laws that cover $100 \%$ of all bars, restaurants and non-hospitality workplaces. ${ }^{3}$ Globally, as of 2010, 174 nations had signed the FCTC and, partially stimulated by it, 87 parties $(50 \%)$ had implemented a policy to protect citizens from SHS exposure in indoor workplaces. ${ }^{29}$ Ireland is one of the pioneering countries that even before ratifying the FCTC had passed comprehensive smoke-free legislation (table 2). Shortly after signing the FCTC, New Zealand and Norway implemented such policies. Since February 2005, when the Treaty entered into force, another 24 countries and all Canadian provinces have implemented comprehensive bans (table 2).

The growing body of evidence on the benefits of smoke-free environments mainly comes from developed countries, but the smoke-free movement has spread further afield. For example, Uruguay became the first Latin American country to pass a nationwide smoke-free policy in 2006, which is in part attributable to the evidence from evaluations of smoke-free laws elsewhere and a strong political backing by the President of the Republic. ${ }^{8}$ Local activists and organisations, such as the Pan American Health Organization and Inter American Heart Foundation in Latin American countries then increased their efforts in other countries. By 2011, seven countries in Latin America had adopted nationwide comprehensive smokefree policies (the most recent, Argentina, occurring in June, 2011). ${ }^{83031}$ Local data have been instrumental in evaluating the effectiveness of smoke-free policies and have been used for advocacy and enforcement purposes. Uruguay and Guatemala, for example, used airborne nicotine levels to show policymakers the levels of exposure that can occur when smoking is allowed and the reasons why smoke-free policies should be as comprehensive as possible. ${ }^{30} 31$ 
More recently, smoke-free environments have been introduced in China. China carries a heavy burden of tobacco-related diseases and also has political constraints due to government ownership of tobacco companies. ${ }^{32}$ However in May 2011, following legislation adopted in local cities, a national smokefree law was adopted. ${ }^{33}$ Although the current legislation is not comprehensive, leaving possible enforcement gaps, it does provide useful lessons to other low-income and middle-income countries.

\section{Issues raised in smoke-free policy debates}

Typically the arguments against implementing smoke-free policies have followed a familiar pattern. When smoke-free policies were first implemented, opponents (frequently organised by the tobacco industry) argued that such policies were not supported by the public, that assuring compliance with the laws would be difficult, that there would be a revenue downturn for the hospitality industry and that ventilation systems were sufficient for protecting customers' and employees' health. ${ }^{34}{ }^{35}$ Each of these points posed a testable hypothesis for empirical research. Epidemiologists, economists and researchers in other fields have carried out studies that demonstrate each of these claims were falsely made. ${ }^{36-44}$ Developed and developing countries' researchers have reached the same conclusions: the vast majority of the population prefers smoke-free places, compliance with smoke-free laws is the norm and there are relatively mild and transient implementation issues. ${ }^{39-43}$ Studies have found that business indicators typically continue to track along pre-existing trends after smoke-free policies are implemented, ${ }^{44}$ and the potential benefits of having such policies far exceed the potential costs. $^{36}$ In addition, ventilation and filtration systems do not eliminate the health risks posed by SHS exposure in the workplace. ${ }^{4546}$ In summary, credible research has played a vital role in policy debates.

An argument proposed to allow smoking areas under ongoing smoke-free policy debates, is that smoking employers could take care of these areas without further compromising their health (eg, waiters who smoke could clean up the smoking section in a restaurant). Two studies showed that secondhand smoke increases the risk of respiratory symptoms in adolescent and adult smokers. 4748

\section{Tobacco industry opposition and obstruction to the smoke-free movement}

The tobacco industry recognised in the late 1970s that the dangers posed by SHS for the non-smoker would be a threat to their viability. In response, they employed a variety of techniques to weaken and delay smoke-free policy implementation. ${ }^{49}$ The tobacco industry conducted research to discredit the health effects of SHS under the guise of a worldwide network of scientific consultants to mislead the media and healthcare advocates. Using false claims of an economic downturn following smoking ban implementation, they also organised the hospitality sector. Another approach used was to offer an alternative solution to a smoke-free policy, known as their 'Accommodation' (smoking and non-smoking sections) programme. ${ }^{50}$ Additionally, the tobacco industry manipulated ventilation standards to support inefficient ventilation systems $^{35} 5152$ and lobbied for measures that significantly weakened or delayed smoke-free policy implementation.

These strategies, implemented at different levels worldwide, were somewhat effective in delaying or obstructing the implementation of smoke-free policies. From a research perspective, the industry has hired scientists to conduct research that would yield data to contest the evidence of the harmful effects of SHS. This research was often overseen by tobacco industry lawyers. ${ }^{53-56}$ A particular example of the capability of the industry to work and collaborate worldwide between and within companies was the 'International Environmental Tobacco Smoke (ETS, or SHS) Consultants Program'. This programme was organised in 1988 by Philip Morris and included consultants from Asia, Europe and the Americas. By the early 1990s the programme was active in 30 countries and was funded by Philip Morris, British American Tobacco/Brown \& Williamson, RJ Reynolds and Japan Tobacco Incorporated. In brief, the programme sought to influence policymakers, media and the public by providing, through their consultants, 'accurate' (pro-industry) information concerning smoking regulations in public places and workplaces, indoor air quality and ventilation standards, and scientific claims regarding SHS. ${ }^{53-56}$

These strategies appear to have been effective in obstructing the implementation of smoke-free policies or having ineffective policies be implemented. For example, in Argentina, in the early 1990s the President's decision to veto an anti-tobacco law that, among other provisions, established the creation of smoke-free environments, was due to behind the scenes tobacco industry pressures through front groups to create an environment that would support the veto. The veto was in great part due to the lobbying of one of the consultants of the 'International ETS Consultants Program'.41 5556 Spain and Chile are just two examples of countries where the industry has been successful in passing smoke-free laws with exemptions (eg, based on revenue from alcohol or venue size) that therefore do not solve the problem of exposure to SHS. ${ }^{57}{ }^{58}$ In Spain since 1994, the tobacco industry supported an unenforceable voluntary agreement between the Madrid local government and the hospitality industry that 'replaces a draft law that would have banned smoking, ${ }^{57}$ However, in January 2011 a new comprehensive law was finally implemented.

Therefore, despite the large body of evidence that supports the implementation of smoke-free policies, the fact that $<11 \%$ of the world population is protected by comprehensive, national smoke-free laws is in great part due to the tobacco industry's interference with evidence-based policymaking. ${ }^{29}$ Healthcare advocates and researchers should not overlook the industry's interest in obstructing smoke-free policies and take them into consideration when fighting for new legislation.

\section{THE PRESENT}

There has been a normative shift with regard to smoking in public places in the span of the first two decades of this journal. Just 20 years ago, very few comprehensive smoke-free policies existed. However, today, it is rare to experience active smoking in public, indoor spaces in dozens of countries around the globe (table 1). Smoke free is now a worldwide initiative that, despite the industry's attempts at interference, is becoming the norm rather than the exception. ${ }^{89}$

What has fuelled this global expansion of smoke-free policies? There are many factors, but critical is Article 8 of the FCTC that obligates ratifying nations to push for stronger smoke-free policies. Prior to ratifying FCTC, only 2 countries had national smoke-free laws, compared to 26 after. The FCTC is a composite recognition of all past evidence showing that SHS is harmful to health and that smoke-free policies reduce exposure while being generally well received without adverse side effects. The dramatic benefits for heart disease and lung cancer burden due to 
Table 1 Countries $100 \%$ smoke free

\begin{tabular}{|c|c|c|}
\hline Country* & Local law approval $\dagger$ & Additional coverage \\
\hline Australia & $\begin{array}{l}\text { First State } 2006 \text { (Tasmania) } \\
\text { Last State } 2010 \text { (Northern Territory) }\end{array}$ & In some states, vehicles with children 5960 \\
\hline Bermuda $^{61}$ & 2006 & \\
\hline Bhutan $^{62}$ & 2005 & \\
\hline British Virgin Islands ${ }^{63}$ & 2006 & \\
\hline Canada & $\begin{array}{l}\text { First Territories } 2004 \text { (Northwest and } \\
\text { Nunavut) } \\
\text { Last Territory } 2009 \text { (Prince Edward Island) }\end{array}$ & $\begin{array}{l}\text { In some territories, vehicles with children. } \\
\text { Outdoor seating and patios are smoke free } \\
\text { as well. }{ }^{64} 65\end{array}$ \\
\hline Cyprus & 2010 & Vehicles with children ${ }^{66}$ \\
\hline England ${ }^{67}$ & 2006 & \\
\hline France $^{68}$ & 2007 & \\
\hline Guatemala $^{69}$ & 2008 & \\
\hline Honduras $^{70}$ & 2010 & \\
\hline Hong Kong & 2006 & Public transport interchanges ${ }^{71}$ \\
\hline Iceland $^{72}$ & 2007 & \\
\hline Iran & 2007 & All roofed areas ${ }^{73}$ \\
\hline Ireland $^{74}$ & 2004 & \\
\hline Lithuania $^{75}$ & 2007 & \\
\hline Maldives $^{76}$ & 2009 & \\
\hline New Zealand & 2003 & Prisons ${ }^{77}$ \\
\hline Northern Ireland ${ }^{78}$ & 2007 & \\
\hline Norway ${ }^{79}$ & 2004 & \\
\hline Panama $^{80}$ & 2008 & \\
\hline Paraguay $^{81}$ & 2010 & \\
\hline Peru $^{82}$ & 2006 & \\
\hline Scotland ${ }^{83}$ & 2006 & \\
\hline Singapore & 2009 & All roofed areas ${ }^{84}$ \\
\hline Spain ${ }^{85}$ & 2011 & \\
\hline Turkey $^{86}$ & 2008 & \\
\hline Uruguay $^{87}$ & 2006 & \\
\hline Wales $^{88}$ & 2006 & \\
\hline
\end{tabular}

SHS, coupled with the lack of any economic impact on the hospitality industry, have also contributed to the rapid spread of this policy. In Guatemala and Uruguay, smoke-free policies represent a clear example of knowledge translation and evidencebased policymaking in which researchers, tobacco control advocates and policymakers have all worked together to move the issue forward. ${ }^{30} 4243$

The types of places covered by smoke-free policies are also in a state of change today in some developed countries. Previously, smoke-free policies have generally been framed as employee and customer protection policies. Today we're seeing an expansion of policies to cover other areas, such as outdoor eating and drinking areas of bars or restaurants and entryways to buildings. As indoor spaces directly adjacent to these areas may already be smoke free, a fairly dense concentration of smokers may be present here at certain points in time and SHS exposures may present health risks. ${ }^{90} 91$ To document this transition, we reviewed all publications on smoke-free environments in the Tobacco Control. Among 238 publications, there has been an increase over time in the number of publications and a shift on the areas included in smoke-free policies, moving from healthcare facilities to private areas (table 2).

Other policies are covering spaces with much greater densities of smokers such as parks and beaches. It is less clear what the adverse health impact of generally transient, low-level exposure in these settings is; however, proponents have also cited environmental issues (eg, litter), ${ }^{92} 93$ quality of life issues and protection of children from role modelling smoking behaviour as reasons why such policies are justified. The evaluation model in figure 1 focuses on reduced SHS as the key endpoint. Research and societal norms should dictate whether these other primary outcome measures justify efforts to implement smoke-free policies in these areas. Still other policies are addressing private areas. These include legislated policies that prohibit smoking in cars with children, now present in 25 jurisdictions worldwide, and legislated policies that require entire multiunit housing complexes to be smoke free, now present in 5 communities in California. ${ }^{94-96}$ In developed countries, non-legislated, voluntary policies in both of these settings are now being implemented with increasing frequency by smokers as well as apartment and condominium property managers and owners.

Yet to been seen is if this change in the expansion of smokefree policies will spread as the indoor smoking policies have. The diffusion of a new innovation or policy often depends on the relative advantage the new innovation will supply, the compatibility of an innovation with the existing values of potential adopters, the complexity and trialability of the innovation, and the degree to which the results of an innovation are visible to others. ${ }^{97}$ The success of past smoke-free policy implementation and the changing norms towards a smoke-free society are both likely to increase smoke-free policy adoption. However, research to better understand how these voluntary 
Table 2 Papers published in Tobacco Control, 1992-2011, on smoke-free environments

\begin{tabular}{|c|c|c|c|c|}
\hline \multirow[b]{2}{*}{ Location of focus } & \multicolumn{4}{|c|}{ Year of publication } \\
\hline & $1992-1996$ & 1997-2001 & $2002-2006$ & $2007-2011$ \\
\hline Healthcare facilities (hospitals, psychiatric units, nursing homes, pharmacies) & 5 & 6 & 4 & 5 \\
\hline Public transportation (aeroplanes, airports, buses, taxis) & 2 & 1 & 7 & 1 \\
\hline Sporting venues & 1 & 0 & 1 & 1 \\
\hline Educational buildings and campuses & 0 & 4 & 4 & 2 \\
\hline Prisons & 1 & 3 & 0 & 5 \\
\hline Public indoor places (malls, churches, temples, museums) & 0 & 2 & 1 & 0 \\
\hline Hospitality venues (hotels, restaurants, cafes, bars, nightclubs, casinos) & 1 & 10 & 44 & 38 \\
\hline Housing & 0 & 4 & 6 & 17 \\
\hline Private vehicles & 0 & 0 & 2 & 3 \\
\hline Outdoor spaces (beaches, parks, building entrances) & 0 & 0 & 0 & 5 \\
\hline Workplaces not specified & 1 & 18 & 15 & 18 \\
\hline Total & 11 & 48 & 84 & 95 \\
\hline
\end{tabular}

A search was conducted on the Tobacco Control website for the keyword 'smoke-free', yielding 682 publications. All titles were reviewed and the ones focused on smoke-free environments were included (238) and classified according to the location of focus. All Tobacco Control issues were included, from the first in March 1992 to the most recent available at time of writing (May 2011).

and legislated policies are implemented, how they are working and what impacts they have are now underway and will be key to informing future smoke-free policy development in these areas worldwide.

\section{Policy evaluation framework}

Many smoke-free policy evaluation models exist and we highlight one model that was developed by International Agency for Research in Cancer (figure 1).98 The main goal of smoke-free policies is to eliminate secondhand smoke exposure and thus to improve health outcomes. Intermediate measures focus on smoke-free policy compliance, which in turn affects SHS exposure and subsequent health outcomes. Furthermore, there are also potential incidental effects of smoke-free regulations such as possible business losses/gains and increased cessation activity among smokers. Other moderating variables, such as industry involvement, or an individual's occupation or occupational status, can come into play at various places in the model.

Some factors to consider include an understanding of the nature of the policies. What areas are covered and are there exemptions or possible loopholes? Within a jurisdiction, there might also be local policies (from local government or businessspecific policies) that may need to be considered. The next step is to consider the impact of these policies on markers of exposure to SHS, which is the key proximal variable of interest.

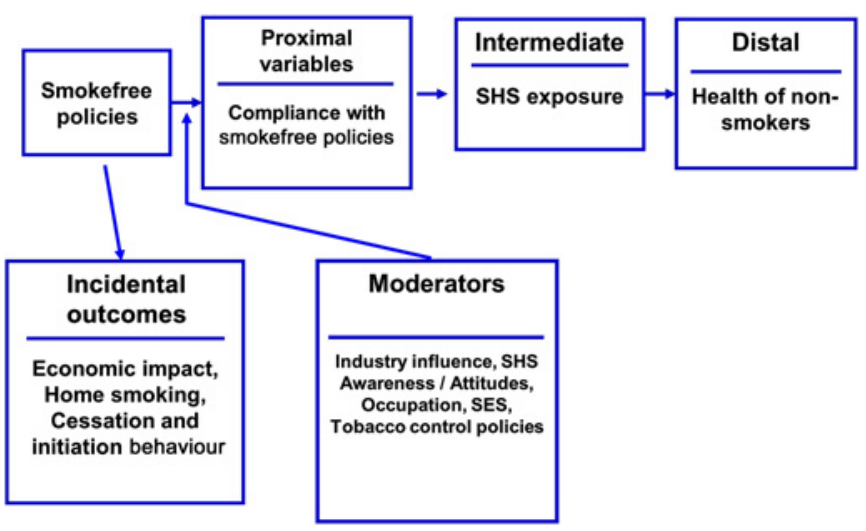

Figure 1 Conceptual framework for the evaluation of smoke-free policies (adapted from International Agency for Research on Cancer (IARC) Monograph 2, Methods for Evaluating Tobacco Control Policies).
Compliance with the policy is critical at this point in the model because poor compliance will weaken the public health benefit of the smoke-free policy and could even result in a backlash where policymakers overturn the policy because it is ineffectual.

More distal variables that may change in response to smokefree policy implementation are people's attitudes, beliefs and practices regarding SHS. For example, local, grass roots movements in scores of local communities in California contributed to public information campaigns and the passage of local-level clean air policies. Policies can change social norms and beliefs and vice versa. There may also be incidental impacts that need to be rigorously studied in order to address concerns about the impact of these policies. One concern that gets raised in nearly every policymaking debate about the merits of smoke-free policies is that its implementation will adversely impact the economy because smokers will stop dining out and going to bars. Often this is the central issue of the debate and credible information addressing this point needs to be obtained. Another key 'incidental' impact is that smoke-free policies tend to reduce cigarette consumption in smokers and they may also influence smoking initiation rates among young people. ${ }^{99}$

From the public health perspective, these are beneficial effects though not the reason why smoke-free policies are considered. Some have argued that smoke-free bar policies will displace smoking from the pubs into the homes of smokers, ${ }^{100}$ thus increasing exposure among family members; however, data indicate this has not occurred. ${ }^{101-105}$ Others have raised concern that smoke-free policies increase the social stigmatisation of smokers, ${ }^{106}$ and that they increase noise and nuisance complaints. ${ }^{107}$ Some are concerned that the credibility of tobacco control practitioners can be undermined by advocating for smoke-free policies, strictly on a health basis, in wide-open places such as parks and beaches. ${ }^{108}$

\section{THE FUTURE}

We envision the future of smoke-free policy research over the next 20 years will follow two paths. First, we will continue to need research to guide and evaluate policies that are pending approval and the current policies that have been implemented. Monitoring tobacco industry tactics to obstruct the implementation and enforcement of smoke-free policies remains a challenge to local researchers and the civil society. To date, compliance with indoor smoking bans in worksites, bars, 
restaurants and other public places has generally been high, with some exceptions. ${ }^{37} 109$ Most smoke-free policies in the past have been well supported by the public, but future policies will likely cover more indoor and outdoor public spaces, and areas that are, in part, private (eg, private vehicles, individual units of multiunit housing buildings). These extensions may be met with some resistance and therefore require careful evaluation and appropriate enforcement. For example, children continue to have high levels of exposure in homes and cars, particularly children from lower SES households. ${ }^{103} 110$ The evaluation model in figure 1 can be adapted to create a research framework to help inform these policy debates.

Second, the future may render 'smoke-free' policies obsolete or dramatically change the policy intent. Some have asked whether 'smoke free' includes non-cigarette forms of tobacco such as shisha or waterpipe smoke. Studies show that the particulate matter that results from burning shisha is comparable to that found from burning cigarettes. ${ }^{111}$ As elevated particulate exposure is related to increased morbidity and mortality, it suggests that these and other combustible tobacco products should be regulated by smoke-free policies. ${ }^{112}$

Many public health advocates have claimed that combustion products are the primary source of tobacco-attributable disease and that non-combustion products, which produce no smoke by definition, should be actively pursued as a means to improve public health. Cigarette companies such as Altria and RJ Reynolds have entered into the smokeless tobacco business, with electric cigarettes such as Accord and compressed tobacco tablets such as Stonewall, but with limited market success. Other companies have looked to market a vast array of noncombustion nicotine containing products from water to lollipops. In very recent times, there has been much discussion in the tobacco control community about electronic nicotine delivery systems, which use battery power to heat a glycogen and nicotine containing solution to a gas phase where it is inhaled by the user. Of course, there is also pharmaceutical grade medicinal nicotine that has been available for many years. It is not clear whether these products will yield public health gains more quickly than established tobacco control strategies such as smoke-free policies, higher tobacco taxation and increased public awareness. Proponents point out that these products are an alternative aid in smoking cessation while critics argue they may foster continued nicotine addiction and are a 'gateway' to promote smoking among young people and sustain the tobacco industry's earnings. ${ }^{113}$ One analysis indicates that noncombustion low nitrosamine smokeless tobacco products are unlikely to produce much public health gain under a variety of scenarios and in some scenarios they can make public health worse depending on how much dual use with cigarettes is occurring. ${ }^{114}$

It is unclear what the future holds for smoke-free policy implementation. For many places that do not have comprehensive smoke-free policies in place, work will continue to expand the areas that provide smoke-free air to citizens. However, we are now in an environment in which the nature of the product and the regulatory environment are changing. For example, some have argued for a reduction in nicotine levels in cigarettes to non-addictive levels. ${ }^{115}$ Others have argued for the government to place caps on the smoking prevalence, which are lowered over time, and to make the tobacco companies accountable for achieving these milestones or else face stiff penalties. ${ }^{116}$ The net impact of these policies would likely dramatically reduce smoking rates and possibly lead to increases in non-combustible nicotine delivery by consumers. In short, the

\section{What this paper adds}

A good deal has been written on the impacts of smoke-free policies. This paper summarises the history, highlights the research underlying smoke-free policies, and examines factors that have contributed to their adoption.

- We speculate on what the smoke-free policies of the future may look like. New tobacco products such as the electronic cigarette will challenge current policies. This paper reviews these implications and the need for new research.

product choices of tomorrow's smokers will play a large role in determining the smoke-free policies of the future.

Acknowledgements We gratefully acknowledge the assistance of Andrea Licht, MS, for her assistance in the preparation of the final manuscript.

Competing interests None.

Provenance and peer review Commissioned; externally peer reviewed.

\section{REFERENCES}

1. Lazuras L, Rodafinos A, Panagiotakos DB, et al. Support for smoke-free policies in a pro-smoking culture: findings from the European survey on tobacco control attitudes and knowledge. Int J Public Health 2009;54:403-8.

2. Vardavas $\mathbf{C l}$, Dimitrakaki C, Schoretsaniti S, et al. The role of the non-smoker in enforcing smoke-free laws. J Public Health Policy 2011;32:46-59.

3. American Non-smokers' Rights Foundation. Smokefree Status of Workplaces and Hospitality Venues Around the World. American Nonsmokers' Rights Foundation, 2011:1-9. http://www.no-smoke.org/pdf/internationalbarsandrestaurants.pdf (accessed 9 Nov 2011).

4. World Health Organization. WHO Framework Convention on Tobacco Control : guidelines for implementation Article 5.3; Article 8; Article 11; Article 13. Geneva, Switzerland: WHO Press, 2009.

5. Institute of Medicine. Secondhand Smoke Exposure and Cardiovascular Effects: Making Sense of the Evidence. Washington DC: The National Academic Press, 2009.

6. Cokkinides V, Bandi P, McMahon C, et al. Tobacco control in the United States-recent progress and opportunities. CA Cancer J Clin 2009:59:352-65.

7. Barnoya J, Glantz S. Association of the California tobacco control program with declines in lung cancer incidence. Cancer Causes Control 2004;15:689-95.

8. International Agency for Research on Cancer WHO. Evaluating the Effectiveness of Smoke-free Policies, Chapter 3: The Evolution of Smoke-Free Policies. Lyon, France: IARC Handbooks of Cancer Prevention, 2009.

9. Public Health Service. Office of the Surgeon General. The Health Consequences of Smoking. National Clearinghouse for Smoking and Health. Washington DC: The Health Consequence of Smoking, 1972.

10. Repace JL, Lowrey AH. Indoor air pollution, tobacco smoke, and public health Science 1980;208:464-72.

11. White JR, Froeb HF. Small-airways dysfunction in nonsmokers chronically exposed to tobacco smoke. N Engl J Med 1980;302:720-3.

12. Hirayama T. Non-smoking wives of heavy smokers have a higher risk of lung cancer: a study from Japan. Br Med J (Clin Res Ed) 1981;282:183-5.

13. Ong E, Glantz SA. Hirayama's work has stood the test of time. Bull World Health Organ 2000;78:938-9

14. Brandt A. The Cigarette Century: The Rise, Fall, and Deadly Persistence of the Product that Defined America. New York, NY: Basic Books, 2007.

15. Kluger R. Ashes to Ashes: America's Hundred-Year Cigarette War, the Public Health, and the Unabashed Triumph of Philip Morris. New York, NY: Vintage Books, 1996

16. US Department of Health and Human Services PHS, Centers for Disease Control. The Health Consequences of Involuntary Smoking: A Report of the Surgeon General. Rockville, MD: Office on Smoking and Health, 1986.

17. US Environmental Protection Agency, Office of Atmospheric and Indoor Air Programs. Respiratory Health Effects of Passive Smoking: Lung Cancer and Other Disorders. Washington, DC, 1992.

18. US Department of Health and Human Services. The Health Consequences of Involuntary Exposure to Tobacco Smoke: A Report of the Surgeon General. Atlanta GA: US Department of Health and Human Services, Centers for Disease Control and Prevention, Coordinating Center for Health Promotion, National Center for Chronic Disease Prevention and Health Promotion, Office on Smoking and Health, 2006.

19. International Agency for Research on Cancer. IARC Monographs on the evaluation of carcinogenic risks to humans - Tobacco smoke and involuntary smoking. Lyon, France: IARCPress, 2002;83. 
20. Bachinger $\mathbf{E}$, McKee M, Gilmore A. Tobacco policies in Nazi Germany: not as simple as it seems. Public Health 2008;122:497-505.

21. Americans for Non-Smokers Rights. Percent of U.S. State Populations Covered by 100\% Smokefree Air Laws. Americans for Non-Smokers Rights, 2011. http:// www.no-smoke.org/pdf/percentstatepops.pdf (accessed 27 Dec 2011).

22. American Non-Smokers' Rights Foundation. Overview List - How many Smokefree Laws? Americans for Non-Smokers Rights, 2011. http://www.no-smoke. org/pdf/mediaordlist.pdf (accessed 27 Dec 2011)

23. The National Academy of Sciences. The Airline Cabin Environment: Air Quality and Safety. Washington, DC: The National Academy of Sciences, 1986.

24. Repace J. Flying the smoky skies: secondhand smoke exposure of flight attendants. Tob Control 2004:13(Suppl 1):i8-19.

25. Neilsen K, Glantz SA. A tobacco industry study of airline cabin air quality: dropping inconvenient findings. Tob Control 2004;13(Suppl 1):i20-9.

26. International Commission on Occupational Health. ICOH Network on Tobacco Free Workplaces. Geneva, Switzerland: International Commission on Occupational Health, 2002. http://www.icohweb.org/site new/ico news detail.asp?id=34 (accessed 18 Aug 2011).

27. Wakefield M, Clegg Smith K, Chapman S. Framing of Australian newspaper coverage of a secondhand smoke injury: lessors for media advocacy. Crit Public Health 2005;15:53-63.

28. World Health Organization. Protection From Exposure to Secondhand-Tobacco Smoke. Policy Recommendations. Geneva: World Health Organization, 2007.

29. World Health Organization. WHO Report on the Global Tobacco Epidemic, 2011 Warning About the Dangers of Tobacco. Geneva, Switzerland: WHO Press, 2011.

30. Navas-Acien A, Peruga A, Breysse P, et al. Secondhand tobacco smoke in public places in Latin America, 2002-2003. JAMA 2004;291:2741-5.

31. Barnoya J, Mendoza-Montano C, Navas-Acien A. Secondhand smoke exposure in public places in Guatemala: comparison with other Latin American Countries. Cancer Epidemiol Biomarkers Prev 2007;16:2730-5

32. Lv J, Su M, Hong Z, et al. Implementation of the WHO framework convention on tobacco control in mainland, China. Tob Control 2011;20:309-14.

33. Xinhua. China Slowly Adopts Tobacco-Free Laws. Beijing: Xinhua, 2011. http:// www.chinadaily.com.cn/china/2011-05/31/content 12614748.htm laccessed 15 Oct 2011).

34. Zelnick J, Campbell R, Levenstein C, et al. Clearing the air: the evolution of organized labor's role in tobacco control in the United States. Int J Health Serv 2008; 38:313-31.

35. Drope J, Bialous SA, Glantz SA. Tobacco industry efforts to present ventilation as an alternative to smoke-free environments in North America. Tob Control 2004;13 (Suppl 1)::41-7.

36. International Agency for Research on Cancer. Evaluating the Effectiveness of Smoke-free Policies, Chapter 4: Impact of Smoke-Free Policies on Businesses, the Hospitality Sector, and Other Incidental Outcomes. Lyon, France: IARC Handbooks of Cancer Prevention, 2009.

37. International Agency for Research on Cancer. Evaluating the Effectiveness of Smoke-free Policies, Chapter 5. Public Attitudes Towards Smoke-Free Policies Including Compliance With Policies. Lyon, France: IARC Handbooks of Cancer Prevention, 2009

38. International Agency for Research on Cancer. Evaluating the Effectiveness of Smoke-free Policies, Chapter 6: Reductions in Exposure to Secondhand Smoke and Effects on Health Due to Restrictions on Smoking. Lyon, France: IARC Handbooks of Cancer Prevention, 2009

39. Hyland A, Cummings KM, Wilson MP. Compliance with the New York City Smoke-Free Air Act. J Public Health Manag Pract 1999;5:43-52.

40. Weber MD, Bagwell DA, Fielding JE, et al. Long term compliance with California's Smoke-Free Workplace Law among bars and restaurants in Los Angeles County. Tob Control 2003:12:269-73.

41. Skeer M, Land ML, Cheng DM, et al. Smoking in Boston bars before and after a $100 \%$ smoke-free regulation: an assessment of early compliance. J Public Health Manag Pract 2004:10:501-7.

42. Barnoya J, Arvizu M, Jones MR, et al. Secondhand smoke exposure in bars and restaurants in Guatemala City: before and after smoking ban evaluation. Cancer Causes Control 2011:22:151-6.

43. Blanco-Marquizo A, Goja B, Peruga A, et al. Reduction of secondhand tobacco smoke in public places following national smoke-free legislation in Uruguay. Tob Control 2010:19:231-4

44. Scollo M, Lal A, Hyland A, et al. Review of the quality of studies on the economic effects of smoke-free policies on the hospitality industry. Tob Control 2003; 12:13-20.

45. Repace J. Controlling tobacco smoke pollution. ASHRAE IAQ Applications $2005 \cdot 6 \cdot 11-15$.

46. Hyland A, Travers MJ, Dresler C, et al. A 32-country comparison of tobacco smoke derived particle levels in indoor public places. Tob Control 2008;17:159-65.

47. Lam TH, Ho LM, Hedley AJ, et al. Secondhand smoke and respiratory ill health in current smokers. Tob Control 2005;14:307-14.

48. Lai HK, Ho SY, Wang MP, et al. Secondhand smoke and respiratory symptoms among adolescent current smokers. Pediatrics 2009:124:1306-10.

49. Glantz SA, Parmley WW. Passive and active smoking. A problem for adults. Circulation 1996:94:596-8.

50. Sebrie EM, Glantz SA. "Accommodating" smoke-free policies: tobacco industry's Courtesy of Choice programme in Latin America. Tob Control 2007;16:e6.
51. Bialous SA, Glantz SA. ASHRAE Standard 62: tobacco industry's influence over national ventilation standards. Tob Control 2002;11:315-28.

52. Campbell RB, Balbach ED. Manufacturing credibility: the National Energy Management Institute and the Tobacco Institute's strategy for indoor air quality. Am J Public Health 2011;101:497-503.

53. Bero L, Barnes DE, Hanauer $\mathrm{P}$, et al. Lawyer control of the tobacco industry's external research program. The Brown and Williamson documents. JAMA 1995;274:241-7.

54. Ong EK, Glantz SA. Constructing "sound science" and "good epidemiology": tobacco, lawyers, and public relations firms. Am J Public Health 2001;91:1749-57.

55. Barnoya J, Glantz S. Tobacco industry success in preventing regulation of secondhand smoke in Latin America: the "Latin Project". Tob Control 2002;11:305-14.

56. Barnoya J, Glantz SA. The tobacco industry's worldwide ETS consultants project: European and Asian components. Eur J Public Health 2006:16:69-77.

57. Muggli ME, Lockhart NJ, Ebbert JO, et al. Legislating tolerance: Spain's national public smoking law. Tob Control 2010;19:24-30.

58. Erazo M, Iglesias V, Droppelmann A, et al. Secondhand tobacco smoke in bars and restaurants in Santiago, Chile: evaluation of partial smoking ban legislation in public places. Tob Control 2010:19:469-74.

59. Government of Western Australia. Delivering a Healthy WA - Smoking Banned in Pubs and Clubs Ministerial Media Statements. 2008. http://www. mediastatements.wa.gov.au/Lists/Statements/DispForm.aspx?1D=115987 (accessed 10 May 2011).

60. Northern Territory Government Department of Health. SmokeFree NT. 2011 http://www.health.nt.gov.au/Alcohol and Other Drugs/Tobacco/SmokeFree NT/ index.aspx (accessed 30 May 2011).

61. Regan N. Smoking Ban Kicks in on Sunday. 2006. http://bermudasun.bm/main asp?SectionlD=24\&SubSection ID=270\&ArticlelD=31037\&TM=10964.17 (accessed 31 May 2011).

62. WHO Regional Office for South-East Asia. Profile on Smoke-free Environments in the South-East Asia Region. New Delhi: WHO Press, 2007

63. Americans for Nonsmokers Rights. British Virgin Islands Report. International. 2006. http://www.no-smoke.org/goingsmokefree.php?id=524 laccessed 31 May 2011).

64. Physicians for a Smoke-Free Canada. Background on Protection from SecondHand Smoke in Canada. Ottawa, Ontario: Physicians for a Smoke-Free Canada, 2007:1-4.

65. Non-Smokers' Rights Association. Provincial and Territorial Legislation: Prince Edward Island, 2011. http://www.nsra-adnf.ca/cms/file/PEI_March_2011.pdf (accessed 27 Dec 2011).

66. Americans for Nonsmokers Rights. Cyprus Report International. 2011. http:// www.no-smoke.org/goingsmokefree.php?id=680 (accessed 31 May 2011)

67. United Kingdom Parliament. Health act 2006, Chapter 28. UK: The Stationery Office Limited, 2006:1-91.

68. Le ministre de la santé et des solidarités. Décret n²006-1386 du 15 novembre 2006. 2006. http://www.legifrance.gouv.fr/affichTexte.do?cidTexte=LEGITEXT 000006054716 ddateTexte $=20110427$ (accessed 11 Jun 2011)

69. Congreso de la Republica de Guatemala. Decreto No 74-2008. Guatemala: Diario de Centroamérica, 2008.

70. Republica de Honduras Congreso Nacional. Entra en vigencia ley antitabaco aprobada el año pasado por iniciativa del presidente del Congreso Juan Orlando Hernández. 2011. http://www.congreso.gob.hn/noticias-y-eventos/noticias/2011/ 1688-entra-en-vigencia-ley-antitabaco-aprobada-el-ano-pasado-por-iniciativa-delpresidente-del-congreso-juan-orlando-hernandez (accessed 31 May 2011).

71. Tobacco Control Office Department of Health. Smoking (Public Health Ordinance. 2007. http://www.tco.gov.hk/textonly/english/legislation/legislation_so. html (accessed 31 May 2011).

72. Iceland is Smoke-Free and Happy. 2007. http://www.icenews.is/index.php/2007/ 10/20/iceland-is-smoke-free-and-happy/ (accessed 31 May 2011).

73. Americans for Nonsmokers Rights. Iran Report International. 2009. http://www. no-smoke.org/goingsmokefree.php?id=630 (accessed 31 May 2011).

74. Americans for Nonsmokers Rights. Ireland Report International. 2011. http:// www.no-smoke.org/goingsmokefree.php?id=179 (accessed 31 May 2011).

75. Seimas of the Republic of Lithuania. Law on Tobacco Control. 2006. http:// www3.Irs.It/pls/inter3/dokpaieska.showdoc I?p id=281045 laccessed 31 May 2011).

76. President ratifies Tobacco Control Bill. Haveeru Online. 2010. http://www haveeru.com.mv/english/details/31834 (accessed 31 May 2011).

77. New Zealand Ministry of Health. Smokefree Law in New Zealand. 2005. http:// www.moh.govt.nz/smokefreelaw (accessed 31 May 2011).

78. Northern Ireland Direct Government Services. Smoking Regulations in Northern Ireland. 2010. http://www.nidirect.gov.uk/index/information-and-services/ health-and-well-being/healthy-living/smoking-regulations-in-northern-ireland.htm (accessed 31 May 2011).

79. Department for Tobacco Control. Directorate for Health and Social Affairs. Norway's Ban On Smoking in Bars and Restaurants: A Review of the First Year. Oslo: Directorate for Health and Social Affairs, 2005.

80. Organo Ejecutivo Nacional PdLR, Republica de Panamá Ley No. 13. Panama City: Gaceta Oficial, Asamblea Nacional, 2008.

81. Americans for Nonsmokers Rights. Paraguay Report International. 2011. http:// www.no-smoke.org/goingsmokefree.php?id=696 (accessed 31 May 2011) 
82. Congreso de la República. Ley 28705 Ley General para la Prevención y Control de los riesgos del consumo de tabaco. Peru, 2006.

83. United Kingdom Parliament. Health and Social Care (Scotland) Act 2005. UK: The Stationery Office Limited, 2006:1-91.

84. Americans for Nonsmokers Rights. Singapore Report International. 2011. http:// www.no-smoke.org/goingsmokefree.php?id=426 (accessed 31 May 2011).

85. Jefatura del Estado. Boletín Oficial del Estado. 2010:109188-94.

86. Americans for Nonsmokers Rights. Turkey Report International. 2011. http:// www.no-smoke.org/goingsmokefree.php?id=646 (accessed 31 May 2011).

87. Americans for Nonsmokers Rights. Uruguay Report International. 2011. http:// www.no-smoke.org/goingsmokefree.php?id=484 (accessed 31 May 2011).

88. World Health Organization. Parties to the WHO Framework Convention on Tobacco Control. 2011. http://www.who.int/fctc/signatories_parties/en/index.html (accessed 27 Apr 2011).

89. Koh HK, Joossens LX, Connolly GN. Making smoking history worldwide. N Engl J Med 2007;356:1496-8.

90. Klepeis NE, Gabel EB, Ott WR, et al. Outdoor air pollution in close proximity to a continuous point source. Atmos Environ 2009:43:3155-67.

91. Gallus S, Rosato V, Zuccaro P, et al. Attitudes towards the extension of smoking restrictions to selected outdoor areas in Italy. Tob Control. Published Online First: 25 May 2011. doi:10.1136/tc.2010.040774.

92. Slaughter $\mathbf{E}$, Gersberg RM, Watanabe K, et al. Toxicity of cigarette butts, and their chemical components, to marine and freshwater fish. Tob Control 2011;20(Suppl 1): $: 25-9$

93. Novotny TE, Hardin SN, Hovda LR, et al. Tobacco and cigarette butt consumption in humans and animals. Tob Control 2011:20(Suppl 1):i17-20.

94. McKinley J. Smoking Ban Extends to Apartments. California: World, Americas, 2009. http://www.nytimes.com/2009/01/27/world/americas/27iht-smoking.1.19706667. html (accessed 11 Jun 2011).

95. Pisillo J. Contra Costa Brings the Smoking Ban Home. 2010. http://www.sfgate com/cgi-bin/blogs/ontheblock/detail?entry id=73424 (accessed 11 Jun 2011).

96. Groff J. Calabasas Gives Final Okay to Apartment Smoking Ban. 2008. http://www. theacorn.com/news/2008-01-24/community/006.html (accessed 11 Jun 2011).

97. Rogers EM. Diffusion of Innovations. 5th edn. New York. NY: The Free Press, 2003.

98. International Agency for Research on Cancer. Methods for Evaluating Tobacco Control Policies. Lyon, France: IARC Handbooks of Cancer Prevention, 2008.

99. Voorhees CC, Ye C, Carter-Pokras 0, et al. Peers, tobacco advertising, and secondhand smoke exposure influences smoking initiation in diverse adolescents. Am J Health Promot 2011;25:e1-11.

100. Ho SY, Wang MP, Lo WS, et al. Comprehensive smoke-free legislation and displacement of smoking into the homes of young children in Hong Kong. Tob Control 2010;19:129-33.
101. Haw SJ, Gruer L. Changes in exposure of adult non-smokers to secondhand smoke after implementation of smoke-free legislation in Scotland: national cross sectional survey. BMJ 2007;335:549.

102. Dove MS, Dockery DW, Connolly GN. Smoke-free air laws and secondhand smoke exposure among nonsmoking youth. Pediatrics 2010;126:80-7.

103. Akhtar PC, Currie DB, Currie CE, et al. Changes in child exposure to environmenta tobacco smoke (CHETS) study after implementation of smoke-free legislation in Scotland: national cross sectional survey. BMJ 2007;335:545

104. Holliday JC, Moore GF, Moore LA. Changes in child exposure to secondhand smoke after implementation of smoke-free legislation in Wales: a repeated crosssectional study. BMC Public Health 2009;9:430

105. Hyland A, Hassan LM, Higbee $\mathrm{C}$, et al. The impact of smokefree legislation in Scotland: results from the Scottish ITC: Scotland/UK longitudinal surveys. Eur J Public Health 2009;19:198-205.

106. Stuber J, Galea S, Link BG. Smoking and the emergence of a stigmatized social status. Soc Sci Med 2008;67:420-30

107. Moore RS, Annechino RM, Lee JP. Unintended consequences of smoke-free bar policies for low-SES women in three California counties. Am J Prev Med 2009:37 (2 Suppl): $: 138-43$.

108. Chapman S. Should smoking in outside public spaces be banned? No. BMJ 2008;337:a2804.

109. Corral JE, Cornejo JA, Barnoya J. Bars' and restaurants' compliance with the Guatemalan smoke-free law during the 2010 Soccer World Cup: a missed opportunity. Tob Control 2011;20:445-6.

110. Moore GF, Holliday JC, Moore LA. Socioeconomic patterning in changes in child exposure to secondhand smoke after implementation of smoke-free legislation in Wales. Nicotine Tob Res 2011;13:903-10.

111. Daher N, Saleh R, Jaroudi $\mathrm{E}$, et al. Comparison of carcinogen, carbon monoxide, and ultrafine particle emissions from narghile waterpipe and cigarette smoking: sidestream smoke measurements and assessment of second-hand smoke emission factors. Atmos Environ 2010:44:8-14.

112. Pope CA 3rd, Burnett RT, Thun MJ, et al. Lung cancer, cardiopulmonary mortality, and long-term exposure to fine particulate air pollution. JAMA 2002;287:1132-41.

113. Melikian AA, Hoffmann D. Smokeless tobacco: a gateway to smoking or a way away from smoking. Biomarkers 2009;14(Suppl 1):85-9.

114. Mejia AB, Ling PM, Glantz SA. Quantifying the effects of promoting smokeless tobacco as a harm reduction strategy in the USA. Tob Control 2010:19:297-305

115. Henningfield JE, Benowitz NL, Slade J, et al. Reducing the addictiveness of cigarettes. Council on Scientific Affairs, American Medical Association. Tob Control 1998:7:281-93

116. Sugarman SD. Performance-based regulation: enterprise responsibility for reducing death, injury, and disease caused by consumer products. J Health Polit Policy Law 2009;34:1035-77. 